\title{
Normal values of serum IGF-1 in adults: results from a Brazilian population
}

\author{
Valores normais de IGF-1 sérico em adultos: \\ resultados de uma população brasileira
}

Pedro Weslley Rosario'

\begin{abstract}
Objective: To determine the normal values of serum IGF-1 (Immulite 2000) in a Brazilian adult (21-70 years) population. Subjects and methods: Healthy volunteers were divided into 10 groups according to age (5-year intervals), with 100 subjects ( 50 men and 50 women) per group. One-hundred participants were selected for repetition of the test after 12 weeks. Results: No difference in IGF-1 values was observed between men and women, but a progressive reduction of serum IGF-1 with age was seen. The reference values provided by the manufacturer of the assay, although discretely higher, were very close to the values found in this study. A second measurement of IGF-1 after 12 weeks revealed a variation $\leq 20 \%$ in $99 \%$ of subjects. Conclusions: This study established the reference range for IGF-1 determined with the Immulite 2000 assay for a large number of healthy Brazilian adults stratified according to age, and suggests that variations $>20 \%$ in IGF-1 levels within an interval of 12 weeks cannot be attributed to interassay variability. Arq Bras Endocrinol Metab. 2010;54(5):477-81
\end{abstract}

Keywords

IGF-1; immulite assay; normal values; adults

\section{RESUMO}

Objetivo: Determinar os valores normais de IGF-1 sérico (Immulite 2000) em uma população adulta (21-70 anos) brasileira. Sujeitos e métodos: Voluntários saudáveis foram divididos em 10 grupos de acordo a idade (intervalos de 5 anos), com 100 indivíduos ( 50 homens e 50 muIheres) por grupo. Cem participantes foram selecionados para repetição do exame após 12 semanas. Resultados: Nenhuma diferença nos valores de IGF-1 foi observada entre homens e mulheres, mas uma redução progressiva do IGF-1 sérico com a idade foi vista. Os valores de referência fornecidos pelo fabricante do ensaio, embora discretamente maiores, foram muito próximos dos encontrados neste estudo. Uma segunda medida do IGF-1 após 12 semanas revelou uma variação $\leq 20 \%$ em $99 \%$ dos indivíduos. Conclusões: Este estudo estabeleceu os valores de referência para o IGF-1 com ensaio Immulite 2000 em um grande número de adultos brasileiros saudáveis e sugere que variações > 20\% nos níveis de IGF-1 com intervalo de 12 semanas não podem ser atribuídas à variabilidade interensaio. Arq Bras Endocrinol Metab. 2010;54(5):477-81

Descritores

IGF-1; ensaio immulite; valores normais; adultos
${ }^{1}$ Programa de Pós-graduação, Santa Casa de Belo Horizonte. Departamento de Neuroendocrinologia, Serviço de Endocrinologia, Santa Casa de Belo Horizonte, MG, Brazil

\section{INTRODUCTION}

Cerum IGF-1 plays an important role in the evalua$\checkmark$ tion of growth hormone $(\mathrm{GH})$ deficiency and excess in adults. With respect to acromegaly, normal serum IGF-1 makes this diagnosis unlikely (1), whereas elevated IGF- 1 is a suspicion of this condition, even when
$\mathrm{GH}$ nadir is $<1 \mu \mathrm{g} / \mathrm{L}$ after an oral glucose overload $(2,3)$. Normalization of IGF-1 is one of the main targets of treatment, and is the only "biochemical control" parameter during $\mathrm{GH}$ receptor antagonist treatment (pegvisomant). In adult GH deficiency, serum IGF-1 selects patients who need to be submitted to provoca- 
tive tests (4), defines severe GH deficiency [low IGF1 (5)], and determines GH dose adjustments during therapy $(4,5)$. In addition, epidemiological studies have associated serum IGF-1 levels with the risk of cardiovascular disease and death and cancer (6).

Despite its importance, there is a lack of studies employing an adequate sample for the definition of IGF-1 reference values using current assays. The only kit (Nichols Advantage) whose reference range was established in a large sample of different populations (7) is not longer available. To our knowledge, there is no study evaluating IGF-1 reference ranges in the Brazilian population. For example, in the case of the assay tested in the present study the reference values are derived from a German population (8).

Some recommendations need to be followed for the definition of IGF-1 reference ranges. The values should be assay-specific $(9,10)$, should be reported according to age (7-16), and should preferentially be population-specific (17). The sample from which these values are extracted should be of adequate size $(7,9)$ and the subjects should be selected rigorously, excluding conditions known to interfere with the levels of this hormone (6). It is also important to know which variations in IGF-1 levels can be attributed to the treatment implemented or to progression of the disease and are not only due to interassay variability (18).

The objective of the present study was to determine the reference range for serum IGF-1 (Immulite 2000 kit) in a Brazilian adult (21-70 years) population and its intraindividual variability after an interval of 12 weeks.

\section{SUBJECTS AND METHODS}

Volunteers of both genders (500 women and 500 men) from the metropolitan region of Belo Horizonte (Minas Gerais, Brazil), ranging in age from 21 to 70 years, with a $\mathrm{BMI} \geq 18.5$ and $\leq 30 \mathrm{~kg} / \mathrm{m}^{2}$ (7) were selected. The subjects were apparently healthy (with no diabetes mellitus, thyroid dysfunction, malignancy or anemia, and no known or clinically suspected renal, hepatic or pituitary disease), eutrophic, and were not taking any potentially interfering medications (contraceptive drugs, estrogens, corticosteroids). The study was approved by the Ethics Committee of Santa Casa de Belo Horizonte.

In addition to clinical examination, all subjects were submitted to minimum laboratory assessment and only those presenting the following parameters were included: fasting glycemia $<100 \mathrm{mg} / \mathrm{dL}, \mathrm{HbAlc}$ $\leq 6 \%$, hemoglobin $\geq 12 \mathrm{~g} / \mathrm{dL}$, serum albumin $\geq$ $3.5 \mathrm{~g} / \mathrm{dL}$, creatinine $\leq 1.2 \mathrm{mg} / \mathrm{dL}, \mathrm{TSH}$ ranging from 0.5 to $4 \mathrm{mIU} / \mathrm{L}$, ALT (alanine transaminase) and AST (aspartate transaminase) $\leq 40 \mathrm{U} / \mathrm{L}$, and bilirubin $\leq 1.2 \mathrm{mg} / \mathrm{dL}$.

Ten groups divided according to age [5-year intervals $(7,8)]$ were pre-defined, with 100 subjects per group $(6,17)$. Since the need of different reference values for men and women is not clear (6), each group was divided into two subgroups ( 50 men and 50 women). Each participant selected was allocated according to gender and age until completing the predefined number of subjects per subgroup.

For the evaluation of interassay variability, 100 participants (5/subgroup) were randomly selected for repetition of the test after 12 weeks. The absence of changes in health and nutritional status during this period was verified and the selection criteria were reevaluated. This time period was defined based on the intervals recommended for the reassessment of IGF-1 after surgery and after the beginning or dose adjustment of medical therapy for acromegaly (19), and after the beginning or adjustments in the GH dose $(4,5)$.

Serumsampleswerecollectedinthemorningafterafast of approximately $10 \mathrm{~h}$. The immunochemiluminescent assay (ICMA) used at various Neuroendocrinology Centers and Clinical Analysis Laboratories in Brazil was chosen [Immulite 2000, Diagnostic Products Corp., Los Angeles, CA; with an analytical sensitivity of 25 $\mu \mathrm{g} / \mathrm{L}$; intra- and interassay coefficient of variation < 8\%; standards calibrated against the WHO IS $87 / 518$ preparation (20); and the reference values provided by the manufacturer $(8)$ are shown in Table 1]. The values obtained at our laboratory for 20 replicates of human serum containing $0 \mu \mathrm{g} / \mathrm{L}$ IGF-1 (standard zero of the Immulite kit) presented $\leq 20 \mu \mathrm{g} / \mathrm{L}$ (analytical sensitivity). For the analysis of imprecision, five different samples (mean concentrations: $52,128,250,516$, and $901 \mu \mathrm{g} / \mathrm{L}$ ) were processed in duplicate over the course of 20 days, two runs per day, for a total number of 40 runs and 80 replicates. Within-run coefficients of variation $(\mathrm{CV})$ for the different levels were $5.1 \%, 4 \%$, $3.2 \%, 4.1 \%$ and $4.8 \%$. Total CV were $7 \%, 5.8 \%, 4.5 \%$, $6 \%$ and $5.7 \%$, respectively.

Because IGF-1 values were not normally distributed in the study population, the reference range was defined as follows: 1) 2.5th and 97.5th percentiles of the values obtained for samples: $(8-11,14,16)$; 
2) logarithmic transformation of the values obtained, calculation of the mean $\pm 2 \mathrm{SD}$ of these values, and exponentiation to obtain the limits corresponding to the original scale $(7-10,12)$. The Student t-test and Kruskal-Wallis test were used to determine differences between groups according to gender $(10-12,14)$. The two-tailed Pearson correlation coefficient test was used to analyze the correlation between age and IGF-1 values in both genders (14) and between the first and second measurement after 12 weeks (18). A p-value < 0.05 was considered to be statistically significant.

Table 1. Reference values (mean \pm 2 SD) provided by the Immulite kit

\begin{tabular}{cc}
\hline Age & Reference values \\
\hline $21-25$ years & $115-345 \mu \mathrm{g} / \mathrm{L}$ \\
$26-30$ years & $116-324 \mu \mathrm{g} / \mathrm{L}$ \\
$31-35$ years & $112-300 \mu \mathrm{g} / \mathrm{L}$ \\
$36-40$ years & $105-280 \mu \mathrm{g} / \mathrm{L}$ \\
$41-45$ years & $97-263 \mu \mathrm{g} / \mathrm{L}$ \\
$46-50$ years & $90-249 \mu \mathrm{g} / \mathrm{L}$ \\
$51-55$ years & $84-236 \mu \mathrm{g} / \mathrm{L}$ \\
$56-60$ years & $78-222 \mu \mathrm{g} / \mathrm{L}$ \\
$61-65$ years & $72-210 \mu \mathrm{g} / \mathrm{L}$ \\
$66-70$ years & $66-198 \mu \mathrm{g} / \mathrm{L}$ \\
$71-75$ years & $61-186 \mu \mathrm{g} / \mathrm{L}$ \\
$76-80$ years & $57-174 \mu \mathrm{g} / \mathrm{L}$ \\
$81-85$ years & $52-164 \mu \mathrm{g} / \mathrm{L}$ \\
\hline
\end{tabular}

\section{RESULTS}

No significant difference in IGF-1 values was observed between men and women in any age group. The maximum difference in the upper limit (97.5th percentile) was $7 \mu \mathrm{g} / \mathrm{L}$ (20 to 30 years) and the maximum difference in the lower limit (2.5th percentile) was $10 \mu \mathrm{g} / \mathrm{L}$ (21 to 25 years). Therefore, similar to previous studies (7-14), the IGF-1 reference values are reported according to age group, without distinction between genders (Table 2). The curves representing the 97.5th, 50th (median) and 2.5th percentiles of IGF-1 as a function of age are shown in figure 1. Pearson's correlation coefficient $(r)$ confirmed the negative correlation between age and IGF- 1 levels both in the total sample of subjects $[\mathrm{r}=-0.61(\mathrm{p}<0.001)]$ and in the analysis by sex $[r=-0.65$ in males $(\mathrm{p}<0.001)$ and $r$ $=-0.58$ in females $(\mathrm{p}<0.001)]$. The upper and lower limits (mean $\pm 2 \mathrm{SD}$ ) provided by the manufacturer (Table 1), although discretely higher, were very close to those obtained in the present study.
Table 2. Mean, median, lower (2.5th percentile, mean - 2 SD) and upper (97.5th percentile and mean $+2 \mathrm{SD}$ ) limit of IGF-1 $(\mu \mathrm{g} / \mathrm{L})$ according to age group

\begin{tabular}{lcccccc}
\hline Age group & $\begin{array}{c}\text { 2.5th } \\
\text { percentile }\end{array}$ & $\begin{array}{c}\text { Mean } \\
\text { - 2 SD* }\end{array}$ & Mean & Median & $\begin{array}{c}\text { 97.5th } \\
\text { percentile }\end{array}$ & $\begin{array}{c}\text { Mean } \\
\mathbf{+ 2 ~ 2 ~ S D * ~}^{*}\end{array}$ \\
\hline 21-25 years & 111 & 110 & 195 & 197 & 334 & 336 \\
26-30 years & 109 & 108 & 187 & 190 & 310 & 312 \\
31-35 years & 106 & 106 & 178 & 178 & 287 & 290 \\
36-40 years & 102 & 100 & 168 & 169 & 265 & 267 \\
41-45 years & 95 & 95 & 165 & 163 & 250 & 253 \\
46-50 years & 87 & 86 & 145 & 145 & 240 & 243 \\
51-55 years & 81 & 80 & 137 & 137 & 220 & 222 \\
56-60 years & 75 & 75 & 129 & 127 & 207 & 210 \\
61-65 years & 68 & 68 & 120 & 121 & 197 & 201 \\
66-70 years & 65 & 65 & 110 & 110 & 185 & 188 \\
\hline
\end{tabular}

* 0 f log-transformed values converted to the corresponding original value.

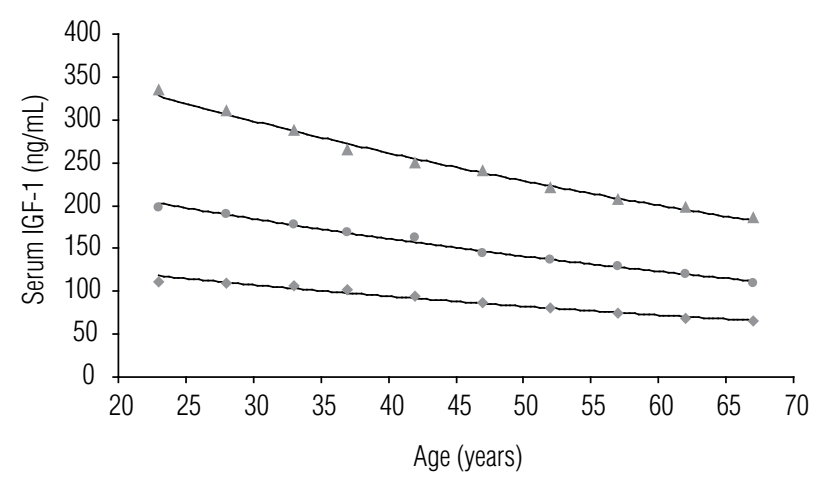

Figure 1. Curves representing the 97.5th, 50th (median) and 2.5th percentiles of IGF-1 as a function of age.

A second measurement of IGF-1 obtained after 12 weeks revealed a variation $\leq 20 \%$ in $99 \%$ of cases, $\leq 15 \%$ in $96 \%$, and $\leq 10 \%$ in $75 \%$. The correlation coefficient (r) was $0.91(\mathrm{p}<0.001)$ despite this variability.

\section{DISCUSSION}

First, some analytical considerations should be made. In the assay tested in this study (Immulite 2000), the standards were calibrated against an international preparation [WHO IS $87 / 518(20)$ ] which, although is not ideal (2l), is the currently most widely used. "Functional separation" (acidification followed by saturation with IGF-II and use of antibodies highly specific for IGF-1) was the technique used to exclude interference from IGF-binding proteins (IGFBPs) (2l). These items (calibration of standards and separation of IGFBPs), together with the specificity of the anti-IGF-1 
antibodies, determine differences between assays. In fact, IGF-1 values obtained for the same sample with different assays can be highly discrepant $(9,10)$. However, as long as the same commercial kit is used, the reference range, if adequately obtained, can be used by other laboratories. Next, we will discuss aspects regarding the establishment of IGF-1 reference values.

The size and selection criteria of the sample are important for the definition of serum IGF-1 reference range in adults. Massart and Poirier (9), studying treated acromegalic patients, found normal IGF-1 levels in only $31 \%$ (DiaSorin) and 36.5\% (Immunotech) using the reference ranges provided by the kits. When adopting limits derived from a sample much larger than that used by the kit's manufacturers for the definition of reference values, the percentages increased to $54 \%$ (DiaSorin) and 61.5\% (Immunotech) (9). Granada and cols. (10), evaluating adults with GH deficiency, observed IGF-1 levels below the lower limit provided by the kits in $77.5 \%$ (Nichols) and $72.5 \%$ (Immulite) of the patients. However, when using limits derived from a significantly smaller sample than that used by the kit's manufacturers to establish the normal reference range, these percentages decreased to $65 \%$ (Nichols) and 58\% (Immulite) (10). These data show that sample size is fundamental for the reliability of the values suggested in the studies. Few studies have included such a large number of participants aged 20 to 70 years as has the present study (7). Furthermore, no other study has applied the Immulite 2000 kit to such a large number of adults $(8)$.

Different conditions can interfere with IGF-1 levels and exclusion of these conditions is an important step in the composition of the sample (6). Asymptomatic conditions such as subclinical thyroid dysfunction are not detected without appropriate laboratory investigation and can therefore influence IGF-1 levels (22). Thus, in addition to clinical examination, laboratory criteria were adopted for inclusion in this investigation, an evaluation not routinely performed in previous studies. The use of medications should also be investigated carefully; for example, eventual differences between genders may in fact be due to the use of contraceptive drugs by women and not to true biological differences (7). Finally, extreme BMI values also influence IGF-1 levels (23); thus, to establish normal reference values the sample should be restricted to subjects with a BMI of approximately 20 to $32.5 \mathrm{~kg} / \mathrm{m}^{2}(7,23)$ as was done in the present study.
The progressive reduction in serum IGF- 1 with increasing age in men and women seen in this study and reported in various other investigations (7-16) indicates the need for age-specific reference ranges. Consensus exists regarding this aspect. However, inappropriate limits might be obtained when the subjects are divided into few and broad age groups since significant variations in IGF-1 are observed within relatively short age intervals. We therefore adopted an interval of 5 years $(7,8)$; nevertheless, differences $>20 \mu \mathrm{g} / \mathrm{L}$ in the upper limit between consecutive age groups were observed in the present study and have also been reported by other investigators $(7,8,16)$.

In the present study, no difference in IGF-1 levels was observed between genders. Many other studies also failed to demonstrate such difference and their results were reported without distinction between genders (714). The hypothesis of a consistent and plausible difference between genders is also weakened by the fact that eventual small differences are not uniform, with some reporting higher IGF-1 levels in men or women depending on their age $(10,15)$ or even on the assay used (10). In the largest study on this subject (7), slightly higher IGF-1 levels (without a significant difference) were observed in men, but the authors themselves attributed this difference to the frequent use of oral contraceptives by the women participating in the study and suggested that there is no need for gender-specific reference values. The exclusion of this interfering factor (use of contraceptive drugs) in the present study might have contributed to the closely similar IGF-1 values observed in men and women.

The need for assay-specific IGF- 1 reference values has been well established. The Immulite 2000 kit is widely used in Brazil and was therefore chosen in the present study. The reference range provided by the manufacturer is derived from the study of Elmlinger and cols. (8), the largest series so far testing this assay in the adult population. In the age range of 21 to 70 years, the reference range reported by Elmlinger and cols. (8) for 315 men and 294 women in Germany was closely similar, but discretely higher than that observed here for 500 men and 500 women. In addition to using the same assay, both studies evaluated a large number of subjects and excluded conditions that would potentially interfere with IGF-l levels, a fact that might have minimized eventual population differences. Both studies [the present one and the study of Elmlinger and cols. (8)] stratified the subjects according to age (5-year intervals) and 
found no difference between genders. These similarities support the adequacy of the reference range proposed here for the adult population when IGF-1 is measured by the Immulite 2000 assay. Nevertheless, a change of the current reference values $(8)$ to those proposed in this study (discretely lower) will result in an increase in the number of patients with elevated IGF- 1 and in a decrease in the number of those with low IGF-1, with an eventual change in the management of these cases whose IGF- 1 values are reclassified from normal to discretely elevated or from low to normal.

Finally, reassessment of IGF-1 levels should be performed within 3 months after surgery and after the beginning or dose adjustment of medical therapy for acromegaly (19). A similar or shorter interval is recommended after the beginning of treatment of adult $\mathrm{GH}$ deficiency or adjustments in the GH dose $(4,5)$. Thus, the period of 12 weeks used in this study for intraindividual measurements seems to be appropriate. The present results indicate that a variation $>20 \%$ cannot be attributed to assay variability alone. In contrast, Milani and cols. (18) reported variation $>20 \%$ in $12 / 84$ subjects $(14.3 \%)$ for measurements made within an interval of only 2 weeks, but no variation $>40 \%$ was observed.

In conclusion, this study has established the reference range for serum IGF-1 determined with the Immulite 2000 assay in a large number of healthy Brazilian adult (21-70 years) subjects $(\mathrm{n}=1,000)$ stratified according to age (without distinction between genders due to similar values). The results also suggest that variations $>20 \%$ in IGF-1 levels within an interval of 12 weeks cannot be attributed to interassay variability.

Acknowledgements and disclosure: This study was supported by grants from Laboratórios Pfizer Ltda.

\section{REFERENCES}

1. Melmed S. Medical progress: acromegaly. $\mathrm{N}$ Engl J Med. 2006;355:2558-73.

2. Dimaraki EV, Jaffe CA, DeMott-Friberg R, Chandler WF, Barkan AL. Acromegaly with apparently normal GH secretion: implications for diagnosis and follow-up. J Clin Endocrinol Metab. 2002;87:3537-42.

3. Freda PU, Reyes CM, Nuruzzaman AT, Sundeen RE, Bruce JN. Basal and glucose-suppressed GH levels less than 1 microg $/ L$ in newly diagnosed acromegaly. Pituitary. 2003;6:175-80.

4. Cook DM, Yuen KC, Biller BM, Kemp SF, Vance ML; American Association of Clinical Endocrinologists. Medical guidelines for clinical practice for growth hormone use in growth hormone-deficient adults and transition patients. Endocr Pract. 2009;15(Suppl 2):1-29.

5. Molitch E, Clemmons DR, Malozowski S, Merriam GR, Shalet SM, Vance ML, for The Endocrine Society's Clinical Guidelines Subcommittee. Evaluation and treatment of adult growth hormone deficiency: an Endocrine Society clinical practice guideline. J Clin Endocrinol Metab. 2006;91:1621-34.

6. Brabant G, Wallaschofski H. Normal levels of serum IGF-l: determinants and validity of current reference ranges. Pituitary. 2007;10:129-33.

7. Brabant G, von zur Mühlen A, Wüster C, Ranke MB, Kratzsch J, Kiess W, et al.; German KIMS Board. Serum insulin-like growth factor I reference values for an automated chemiluminescence immunoassay system: results from a multicenter study. Horm Res. 2003;60:53-60.

8. Elmlinger MW, Kühnel W, Weber MM, Ranke MB. Reference ranges for two automated chemiluminescent assays for serum insulin-like growth factor I (IGF-I) and IGF-binding protein 3 (IGFBP-3). Clin Chem Lab Med. 2004;42:654-64.

9. Massart C, Poirier JY. Serum insulin-like growth factor-I measurement in the follow-up of treated acromegaly: comparison of four immunoassays. Clin Chim Acta. 2006;373:176-9.

10. Granada ML, Ulied A, Casanueva FF, Pico A, Lucas T, Torres E, et al. Serum IGF-I measured by four different immunoassays in patients with adult GH deficiency or acromegaly and in a control population. Clin Endocrinol (Oxf). 2008;68:942-50.

11. Ghigo E, Aimaretti G, Gianotti L, Bellone J, Arvat E, Camanni F. New approach to the diagnosis of growth hormone deficiency in adults. Eur J Endocrinol. 1996;134:352-6.

12. Hilding A, Hall K, Wivall-Helleryd IL, Saaf M, Melin AL, Thoren M. Serum levels of insulin-like growth factor-I in 152 patients with growth hormone deficiency, aged 19-82 years, in relation to those in healthy subjects. J Clin Endocrinol Metab. 1999;84:2013-9.

13. Nyström FH, Ohman PK, Ekman BA, Osterlund MK, Karlberg BE, Arnqvist HJ. Population-based reference values for IGF-I and IGFbinding protein-1: relations with metabolic and anthropometric variables. Eur J Endocrinol. 1997;136:165-72.

14. Aimaretti G, Boschetti M, Corneli G, Gasco V, Valle D, Borsotti $M$, et al. Normal age-dependent values of serum insulin growth factor-I: results from a healthy Italian population. J Endocrinol Invest. 2008;31:445-9.

15. Landin-Wilhelmsen K, Lundberg PA, Lappas G, Wilhelmsen L. Insulin-like growth factor I levels in healthy adults. Horm Res. 2004;62(Suppl 1):8-16.

16. Vierhapper H, Heinze G, Gessl A, Exner M, Bieglmayr C. Use of the oral glucose tolerance test to define remission in acromegaly. Metabolism. 2003;52:181-5.

17. Donangelo I, Une K, Gadelha M. Diagnóstico e tratamento da acromegalia no Brasil. Arq Bras Endocrinol Metab. 2003;47:331-46.

18. Milani D, Carmichael JD, Welkowitz J, Ferris S, Reitz RE, Danoff A, et al. Variability and reliability of single serum IGF-I measurements: impact on determining predictability of risk ratios in disease development. J Clin Endocrinol Metab. 2004;89:2271-4.

19. Growth Hormone Research Society; Pituitary Society. Biochemical assessment and long-term monitoring in patients with acromegaly: statement from a joint consensus conference of the Growth Hormone Research Society and the Pituitary Society. J Clin Endocrinol Metab. 2004;89:3099-102.

20. Bristow AF, Gooding RP, Das RE. The International Reference Reagent for insulin-like growth factor-I. J Endocrinol. 1990;125:191-7.

21. Ranke MB, Feldt-Rasmussen $U$, Bang $P$, Baxter RC, Camacho-Hübner $C$, Clemmons DR, et al. How should insulin-like growth factor I be measured? A consensus statement. Horm Res. 2001;55(Suppl 2):106-9.

22. Akin F, Bastemir M, Yaylali GF, Alkis E, Kaptanoglu B. GH/IGF-1 axis in patients with subclinical hypothyroidism. Clin Endocrinol (Oxf). 2008;68:1009-10.

23. Schneider HJ, Saller B, Klotsche J, März W, Erwa W, Wittchen HU, et al. Opposite associations of age-dependent insulin-like growth factor-I standard deviation scores with nutritional state in normal weight and obese subjects. Eur J Endocrinol. 2006;154:699-706. 